\title{
Central actions of somatostatin in the generation and control of breathing
}

\author{
ISABEL LLONA and JAIME EUGENÍN
}

Laboratory of Neural Systems, Department of Biology, Universidad de Santiago de Chile, Santiago, Chile

\begin{abstract}
The neuropeptide somatostatin is involved in many functions in the central nervous system as well as in the periphery. When it is centrally injected, an irreversible apnea is often developed. In the present review, we discuss the effects of somatostatin as the result of its actions at three levels of the respiratory neural network: a) by modulating the output of cranial or spinal motoneurons; b) by altering the genesis of the respiratory rhythm in the brainstem; and c) by regulating the chemosensory drive input into the respiratory pattern generator.
\end{abstract}

Key terms: apnea, brainstem, chemoreceptors, respiratory rhythm.

The respiratory pattern generator (RPG) is a neuronal network localized in the brainstem responsible for generating the pattern of repetitive motor activity necessary for breathing. The efferent pathway of the RPG commands the cranial and spinal motoneurons that innervate the respiratory muscles. The RPG integrates information from many areas of the CNS, including the cortex, hypothalamus, cerebellum, pons and medulla, and receives information about basic sensory modalities from pulmonary mechanoreceptors as well as central (Nattie, 1999) and peripheral chemoreceptors (Zapata \& Larraín, 2005). As the result of these multiple interactions, breathing is a highly regulated process constrained by allometric (Günther \& Morgado, 2003) and optimization rules (Tehrani, 2003).

Somatostatin (SST) was first identified as a hypothalamic factor, which inhibits the release of growth hormone from anterior pituitary (Brazeau et al., 1973). Both SST and its receptors (SSTR) were subsequently found distributed in several extra-hypothalamic areas of the central nervous system (Finley et al., 1981; Johanson et al., 1984; Moller et al., 2003) and the periphery (Lewin, 1992) in the adult as well as in the developing organism. The widespread distribution of SST suggests that SST is involved in multiple biological functions. The site and dose of SST administration are critical for revealing its respiratory effects. In contrast to earlier works (Niewoehner et al., 1983), Kalia et al. (1984) found that injection of 6 nmol of SST in the cisterna magna of anaesthetized rats produces apnea that was usually irreversible. Actual evidence shows that SST may affect respiration via mechanisms operating at three distinct levels of the central respiratory network: a) by modulating the output of cranial and spinal motoneurons; b) by altering respiratory rhythmogenesis in the brainstem; and c) by regulating the chemosensory drive to the RPG. We will summarize some of the evidence on the localization of SST in the brainstem before we review the evidence on central actions of SST at these three levels.

Corresponding author: Dr. Isabel Llona, Laboratorio de Sistemas Neurales, Depto. Biología, Facultad de Química y Biología, Universidad de Santiago de Chile, Casilla 40, Correo 33, Santiago, Chile, Fax: (56-2) 681-2108, E-mail: illona@lauca.usach.cl 
SOMATOSTATIN LOCALIZATION IN THE

BRAINSTEM RESPIRATORY GROUPS

Mammalian forebrain and hypothalamic areas contain a relatively large amount of SST, while lower brainstem contains a small amount of SST. In the brainstem, SST can be detected in somata and terminals of several nuclei related to the central respiratory groups (Kalia et al., 1984; Leibstein et al., 1985; Llona et al., 2001; Stornetta et al., 2003), the auditory central pathways (Wynne et al., 1995; Kungel \& Friauf, 1995) and brainstem nuclei related to autonomic regulation, like the parabrachial nucleus or the nucleus of tractus solitarius (NTS) (Block \& Hoffman, 1987; Saha et al., 2002). As other neuropeptides (Najimi et al., 2001), the level of expression of SST varies with the age of the animal. Numerous SSTpositive structures in the lower brainstem have been detected in the neonatal rat, but not in the adult rat (Shiosaka et al., 1981; Fitzpatrick-McElligott, et al., 1991; Kungel and Friauf, 1995).

Using in situ hybridization, Shiraishi et al. (1993) were able to detect SST mRNA in the brainstem of adult rats in the same areas where it is found in the neonatal period, suggesting that some expression of the gene is present in the adult stage. Also, SSTR show transient appearance in several brain regions, for example SSTR4 (SST receptor type 4) is expressed transiently and successively replaced by SSTR 1 in the brainstem of the neonatal rat (Wulfsen et al., 1993). The first report that SST was present in neurons and terminals of the preBötzinger complex, a nuclei localized in the ventrolateral medulla and proposed to be the site of respiratory rhythm generation (Feldman et al., 2003; Smith et al., 1991), was obtained in the newborn mouse (Llona et al., 2001). Recently, Stornetta et al. (2003) showed in the adult rat that SST-positive neurons in the pre-Bötzinger complex also contain glutamate as neurotransmitter. It is possible that pre-synaptic SST actions could play a role modulating glutamate release in the pre-Bötzinger. In other glutamatergic terminals, like cerebrocortical nerve endings, SST through activation of pre-synaptic sst2 receptors inhibits the adenylyl cyclase- protein kinase A pathway, which, in turn, reduces the glutamate release (Grilli et al., 2004).

The temporal and spatial patterns of expression of SST and SSTR suggest that SST plays a role in specific brain areas during restricted and precise periods of the development of the nervous system. In has been described that depletion of SST during early development affects the branching density of the dendrites in the rat's lateral superior olive, an auditory brainstem nucleus (Kungel et al., 1997), suggesting that the peptide can exert a trophic role during the neurogenesis and synaptogenesis of the lower brainstem. On the other hand, an abnormal persistence of the density of binding sites to SST at high levels have been detected in the brainstem of infants who died from Sudden Infant Death Syndrome (SIDS), the primary cause of death in human infants aged between 1 and 12 months in industrialized countries (Carpentier et al., 1998). In this syndrome, a defect in the neuroregulation of the cardiorespiratory system is strongly suspected (Kinney et al., 2001) and a high frequency of episodes of prolonged central apneas have been reported in infants who subsequently died of SIDS (Schechtman et al., 1991).

As far as localization is concerned, SST may exert a role in the generation and or control of respiration because both the peptide and its receptors are present in the respiratory groups of the brainstem.

\section{ACTION OF SST ON RESPIRATION}

As mentioned before, Kalia et al. (1984) found that injection of SST in the cisterna magna of anaesthetized rats produces apnea that was usually irreversible. The site of action of SST was suggested to be the dorsal respiratory neurons. When the injection site was more clearly defined, it was found that SST injected in the ventrolateral medulla, in particular in the nucleus paragigantocellularis lateralis of cats and rats, consistently caused apnea (Yamamoto et al., 1988; Chen et al., 1990) suggesting that SST contributes to the central regulation of respiration acting at 
some critical point within the ventral respiratory group. In the rat, SST and Substance $\mathrm{P}$ have antagonistic effects on respiratory regulation in medulla oblongata (Chen et al., 1991). SST-induced apnea can be prevented by central and peripheral administration of an opiate receptor antagonist, like naloxone (Harfstrand et al., 1985), suggesting that SST-induced apnea is mediated by activation of opioid receptors. Aspartic acid depression of ventilation has been suggested to be due to release of SST, but it is not clear if this is a peripheral or central action (Schenker \& Hoffman, 1996).

\section{SST INTERACTION WITH MOTONEURONS}

For a direct interaction between SST and motoneurons, the presence of SSTR located on the motoneurons is a requisite. There are some pieces of evidence pointing in this direction. For example, SSTR2 has been detected in rat nucleus ambiguous and hypoglossal motor nucleus (Breder et al., 1992). In rat lumbar motoneurons, SSTR3 has been detected (Segond von Banchet et al., 1999), and by in situ hybridization, the mRNA for SSTR3 was visualized in motoneurons of cranial nerves, including the facial and the hypoglossal nuclei (Señaris et al., 1995). However, binding of SST could not be detected (Reubi \& Maurer, 1985; Uhl et al., 1985) by autoradiography at this level. Low to moderate concentrations of SST-positive nerve endings are found surrounding the motor cranial nerve nuclei (Johansson et al., 1984). Although SSTR- and SST-positive nerve endings have been described in the respiratory motoneurons of the brainstem, and SST hyperpolarizes vagal motoneurons (Oomura \& Mizuno, 1986), the possibility that SST-induced apnea is due, in part, to interaction with the cranial motoneurons remains to be elucidated.

\section{INTERACTION WITH RPG}

With regard to the generation of the respiratory rhythm, SST-positive neurons could be part of the network that generates the respiratory rhythm or be neuromodulators. SST is present in inspiratory neurons of the pre-Bötzinger complex (Llona et al., 2001; Stornetta et al., 2003), the proposed site of respiratory rhythm generation. This localization suggests that SST is in neurons belonging to the RPG. However, SST is not essential for the generation of the rhythm, because null mutant mice lacking somatostatin seem healthy, fertile, and superficially indistinguishable from their heterozygous and wild-type littermates (Zeyda et al., 2001). The presence of SSTR in the preBötzinger complex has not been determined, and the projections of the SST neurons into this nucleus are not yet defined.

\section{INTERACTION WITH CHEMOSENSORY DRIVE}

The SST administration in the ventrolateral medulla resulted in a blunted ventilatory response to hypoxia and hypercapnia (Chen et al., 1990). Moreover, hypoxia and hypercapnia shortened the latency of SSTinduced apnea, indicating an interaction between chemoreception and SST actions (Harfstrand et al., 1984).

In humans, intravenous infusion of SST greatly reduces the ventilatory response to hypoxia without changing the ventilatory response to hypercapnia (Maxwell 1986; Filuk 1988). In both studies, a central effect cannot be discarded because very high doses were used and some SST can cross the brain blood barrier (Banks et al., 1990). SST has been localized within nerve fibers innervating the arterial chemoreceptor (Kummer, 1989; Kameda, 1989) and inhibits whole cell calcium currents recorded from chemoreceptor glomus (type 1) cells from rat carotid bodies (e Silva, 1995). These results, together with those of Pedersen et al. (1999), suggest that the most likely site of action of SST on hypoxic ventilatory response is the carotid body. On the other hand, under chronic hypoxia, SST gene expression is unchanged (Mosqueira et al., 2004), suggesting that it most likely does not contribute to the functional 
changes induced by hypoxia (Del Río et al., 2004). The ventilatory response to $\mathrm{CO}_{2}$ was not modified by peripheral administration of octreotide, an analogue of SST (Cao et al., 1998), pointing to a central interaction between SST and chemoreception.

In vitro preparations of the central nervous system have been useful for studying mechanisms of breathing control by central chemoreceptors (Nattie, 1999; Eugenín et al., 2001). Using the neonatal mouse medullary-spinal cord preparation, we showed that the interaction between SST and hypercapnia occurs at the central level (Llona et al., 2004). Somatostatin decreased both frequency and amplitude of fictive respiration. The inhibition of respiratory frequency was greater during acidification of the medium than in basal conditions. SST depression of respiration does not seems to depend on the basal state of the respiratory network, because it was not correlated with the basal frequency of the preparation or with the age of the pup from which the brainstem was obtained. At the present time, it is unclear how SST and the chemosensory input may interact within the brainstem to regulate respiration. In our preparation, influences from pontine respiratory groups or peripheral chemoreceptors were absent. Therefore, the actions of SST on respiration are probably at the level of the dorsal and/or ventral respiratory groups of the medulla.

In addition, there is some interaction between chemoreceptors and SST in the control of the tracheal wall tension. The tracheal tension decreased as well as the phrenic nerve activity when SST was applied to the surface of ventral medulla in animals that were hypercapnic (Haxhiu et al., 1993a). Also, application of SST to the surface of the ventral medulla attenuated the response to hypoxia, decreasing the tracheal pressure response. Both effects were abolished after muscarinic blockade suggesting an indirect effect of the peptide. Thus, SST administered in the surface of the ventral medulla modulates parasympathetic outflow to the airway smooth muscle.

The origin of SST in the surface of the ventral medulla may be, at least in part, in the paraventricular and lateral hypothalamic areas that project to the ventrolateral medulla including the airway-related vagal preganglionic neurons (Haxhiu, 1993b).

In summary, these results point to a interaction between SST and central chemoreception in the control of breathing. Several nuclei have been demonstrated to have chemosensory properties (Nattie, 1999), and they can be considered as candidates for localizing the neural circuits where these interactions take place. The SST effects on hypoxic response are most probably of peripheral origin (carotid bodies), while on the contrary, the SST interaction with the chemosensory drive takes place somewhere at the ventral respiratory group of the brainstem.

\section{CONCLUSIONS}

SST acting at different levels within the central nervous system contributes to the control of respiration. Although this neuropeptide is not crucial for rhythm generation, it is involved in the modulation of the respiratory rhythm. This modulation is in part related to the interaction between SST and central chemoreception, through which, SST can influence an important tonic input driving respiration.

\section{ACKNOWLEDGEMENTS}

This work was supported by Fondecyt \#100025 and DICYT \#020343LL. This article is dedicated to Dr. Patricio Zapata who inspired many generations of students during his course of neurophysiology.

\section{REFERENCES}

BANKS WA, SCHALLY AV, BARRERA CM, FASOLD MB, DURHAM DA, CSERNUS VJ, GROOT $\mathrm{K}$, KASTIN AJ (1990) Permeability of the murine bloodbrain barrier to some octapeptide analogs of somatostatin. Proc Natl Acad Sci USA 87: 6762-6766

BLOCK CH, HOFFMAN GE (1987) Neuropeptide and monoamine components of the parabrachial pontine complex. Peptides 8: 267-283

BRAZEAU P, VALE $W$, BURGUS $N$, LING $N$, BUTCHER M, RIVIER J, GUILLEMIN R (1973) Hypothalamic polypeptide that inhibits the secretion of immunoreactive pituitary growth hormone. Science 179: 77-79 
BREDER CC, YAMADA Y, YASUDA K, SEINO S, SAPER CB, BELL GI (1992) Differential expression of somatostatin receptor subtypes in brain. J Neurosci 12: $3920-3934$

CAO K, GRUNSTEIN RR, HO KY, SULLIVAN CE (1998) The effect of octreotide on breathing and the ventilatory response to $\mathrm{CO} 2$ in conscious dogs. Eur Respir J 11: 1376-1381

CARPENTIER V, VAUDRY H, MALLET E, LAQUERRIÈRE A, LEROUX P (1998) Increased density of somatostatin binding sites in respiratory nuclei of the brainstem in sudden infant death syndrome. Neuroscience 86: 159-166

CHEN Z, HEDNER T, HEDNER J (1990) Local application of somatostatin in the rat ventrolateral brain medulla induces apnea. J Appl Physiol 69: 2233-2238

CHEN Z, ENGBERG G, HEDNER T, HEDNER J (1991) Antagonistic effects of somatostatin and substance $\mathrm{P}$ on respiratory regulation in the rat ventrolateral medulla oblongata. Brain Res 556: 13-21

DEL RÍO R, REY S, ARIAS P, ALCAYAGA J, ITURRIAGA R (2004) Chronic intermittent hypoxia enhances chemosensory and ventilatory responses to acute hypoxia. Biol Res 37: R-90

e SILVA MJM, LEWIS DL (1995). L- and N-type Ca channels in rat carotid body chemoreceptor type 1 cells. J Physiol 489: 689-699

EUGENÍN JL, LLONA I, INFANTE CD, AMPUERO E (2001) In vitro approach to the chemical drive of breathing. Biol Res 34: 117-122

FELDMAN JL, MITCHELL GS, NATTIE EE (2003) Breathing: Rhythmicity, plasticity, chemosensitivity. Annu Rev Neurosci 26: 239-266

FILUK RB, BEREZANSKI DJ, ANTHONISEN NR (1988) Depression of hypoxic ventilatory response in human by somatostatin. J Appl Physiol 65: 1050-1054

FINLEY J, MADERDRUT J, ROGER L, PETRUSZ P (1981) The immunocytochemical localization of somatostatin-containing neurons in the rat central nervous system. Neuroscience 6: 2173-2192

FITZPATRICK-MCELLIGOTT S, CARD JP, O'KANE TM, BALDINO F Jr (1991) Ontogeny of somatostatin mRNA-containing perikarya in the rat central nervous system. Synapse 7: 123-134

GRILLI M, RAITERI L, PITTALUGA A (2004) Somatostatin inhibits glutamate release from mouse cerebrocortical nerve endings through presynaptic sst2 receptors linked to the adenylyl cyclase-protein kinase A pathway. Neuropharmacology 46: 388-396

GÜNTHER B, MORGADO E (2003) Dimensional analysis revisited. Biol Res 36: 405-410

HARFSTRAND A, KALIA M, FUXE K, KAIJSER L, AGNATI L (1984) Somatostatin-induced apnea: Interaction with hypoxia and hypercapnia in the rat. Neurosci Lett 50: 37-42

HARFSTRAND A, FUXE K, KALIA M, AGNATI L (1985) Somatostatin induced apnea: Prevention by central and peripheral administration of the opiate receptor blocking agent naloxone. Acta Physiol Scand 125(1): 91-95

HAXHIU MA, DEAL EC, VAN LUTEREN E, CHERNIAK NS (1993a) Central effects of somatostatin and atrial natriuretic peptide on tracheal tone. J Appl Physiol 75(6): 2353-2359

HAXHIU MA, JANSEN AS, CHERNIACK NS, LOEWY AD (1993b) CNS innervation of airway-related parasympathetic preganglionic neurons: A transneuronal labeling study using pseudorabies virus. Brain Res 618: 115-134
JOHANSSON O, HÖKFELT T, ELDE RP (1984) Immunohistochemical distribution of somatostatin-like immunoreactivity in the central nervous system of the adult rat. Neuroscience 13: 265-339

KALIA M, FUXE K, AGNATI L, HÖKFELT T, HÄRFSTRAND A (1984) Somatostatin produces apnea and is localized in medullary respiratory nuclei: A possible role in apneic syndromes. Brain Res 296: 339344

KAMEDA Y (1989) Distribution of CGRP-, somatostatin-, galanin-, and substance P-immunoreactive fibers in the chicken carotid body. Cell and Tissue Res 257: 623629

KINNEY HC, FILIANO JJ, WHITE WF (2001) Medullary serotoninergic network deficiency in the sudden infant death syndrome: Review of a 15-year study of a single data set. J Neuropathol Exp Neurol 60: 228-247

KUMMER W, GIBBINS IL, HEYM CH (1989) Peptidergic innervation of arterial chemoreceptors. Arch Hist Cytol 52(suppl): 361-364

KUNGEL M, FRIAUF E (1995) Somatostatin and leuenkephalin in the rat auditory brainstem during fetal and postnatal development. Anat Embryol 191: 425443

KUNGEL M, PIECHOTTA K, RIETZEL H, FRIAUF E (1997) Influence of the neuropeptide somatostatin on the development of dendritic morphology: A cysteamine-depletion study in the rat auditory brainstem. Brain Res Dev Brain Res 101: 107-114

LEIBSTEIN AG, DERMITZEL R, WILLENBERG IM, PAUSCHERT R (1985) Mapping of different neuropeptides in the lower brainstem of the rat: With special reference to the ventral surface. J Auton Nerv Syst 14: 299-313

LEWIN M (1992) The somatostatin receptor in the GI tract. Annu Rev Physiol 54: 455-468

LLONA I, FARÍAS P, EUGENÍN JL (2001) Presence of somatostatin immunoreactive neurons in the brainstem of neonatal mouse. Soc Neurosci Abs 27: 173-211

LLONA I, AMPUERO E, EUGENÍN JL (2004) Somatostatin inhibition of fictive respiration is modulated by $\mathrm{pH}$. Brain Res 1026: 136-142

MAXWELL DL, CHAHAL P, NOLOP KB, HUGHES JM. (1986) Somatostatin inhibits the ventilatory response to hypoxia in humans. J Appl Physiol 60: 997-1002

MOLLER LN, STIDSEN CE, HARTMANN B, HOLST JJ (2003) Somatostatin receptors. Biochem Biophys Acta 1016: $1-84$

MOSQUEIRA M, VELÁSQUEZ L, ITURRIAGA R (2004) Gen pattern expression of carotid body under chronic hypoxia. Biol Res 37: R-107.

NAJIMI M, BENNIS M, MOYSE E, CHIGR F (2001) Distribution of delta sleep-inducing peptide in the newborn and infant human hypothalamus: An immunohistochemical study. Biol Res 34: 31-42.

NATTIE EE (1999) CO2, brainstem chemoreceptors and breathing. Prog Neurobiol 59: 299-331

NIEWOEHNER DE, LEVINE AS, MORLEY JE (1983) Central effects of neuropeptides on ventilation in the rat. Peptides 4(3): 277-281

OOMURA Y, MIZUNO Y (1986) Effect of somatostatin on the vagal motor neuron in the rat. Brain Res Bull 17: 397-401

PEDERSEN MEF, DORRINGTON KL, ROBBINS PA (1999) Effects of somatostatin on the control of breathing in humans. J Physiol 521: 289-297

REUBI JC, MAURER R (1985) Autoradiographic mapping of somatostatin receptors in the rat central nervous system and pituitary. Neuroscience 15: 1183-1193 
SAHA S, HENDERSON Z, BATTEN TFC (2002) Somatostatin immunoreactivity in axon terminals in rat nucleus tractus solitarii arising from central nucleus of amygdala: Coexistence with GABA and postsynaptic expression of sst2A receptor. J Chem Anat 24: 1-13

SCHECHTMAN VL, HARPER RM, WILSON AJ, SOUTHALL DP (1991) Sleep apnea in infants who succumb to the sudden infant death syndrome. Pediatrics 87: 841-846

SCHLENKER EH, HOFFMAN CS (1996) Cysteamine and naloxone attenuate aspartic acid-induced depression of ventilation. Physiol Behav 59: 709-712

SEGOND VAN BANCHET G, SCHINDLER $M$, HERVIEU GJ, BECKMANN B, EMSON PC, HEPPELMANN B (1999) Distribution of somatostatin receptor subtypes in rat lumbar spinal cord examined with gold-Iabelled somatostatin and anti-receptor antibodies. Brain Res 816: 254-257

SEÑARIS RM, SCHINDLER M, HUMPHREY PPA, EMSON PC (1995) Expression of somatostatin receptor $3 \mathrm{mRNA}$ in the motoneurones of the rat spinal cord, and the sensory neurons of the spinal ganglia. Mol Brain Res 29: 185-190

SHIOSAKA $S$, TAKATSUKI K, SAKANAKA $M$, INAGAKI S, TAKAGI H, SENBA E, KAWAI Y, TOHYAMA M (1981) Ontogeny of somatostatincontaining neuron system of the rat: Immunohistochemical observations. I. Lower brainstem. J Comp Neurol 203: 173-188

SHIRAISHI S, KURIYAMA K, SAIKA T, YOSHIDA S, LIN LP, KITAJIRI M, YAMASHITA T, KUMAZAWA T, SHIOSAKA S (1993) Autoradiographic localization of somatostatin mRNA in the adult rat lower brainstem: Observation by the double illumination technique. Neuropeptides 24: $71-79$
SMITH JC, ELLENBERGER HH, BALLANYI K, RICHTER DW, FELDMAN JL (1991) Pre-Bötzinger complex: A brainstem region that may generate respiratory rhythm in mammals. Science 254: 726-729

STORNETTA RL, ROSIN D, WANG H, SEVIGNY CP, WESTON MC, GUYENET PG (2003) A group of glutamatergic interneurons expressing high levels of both neurokinin-1 receptors and somatostatin identifies the region of the pre-Bötzinger complex. J Comp Neurol 455: 499-512

TEHRANI FT (2003) Function of brainstem neurons in optimal control of respiratory mechanics. Biol Cybern 89: 163-169

UHL GR, TRAN V, SNYDER SH, MARTIN JB (1985) Somatostatin receptors: Distribution in rat central nervous system and human frontal cortex. J Comp Neurol 24: 288-304

WYNNE B, HARVEY AR, ROBERTSON D, SIRINATHSINGHJI DJ (1995) Neurotransmitter and neuromodulator systems of the rat inferior colliculus and auditory brainstem studied by in situ hybridisation. J Chem Neuroanat 9: 289-300

WULFSEN I, MEYERHOF W, FEHR S, RICHTER D (1993) Expression patterns of rat somatostatin receptor genes in pre- and post-natal brain and pituitary. J Neurochem 61: 1549-1552

YAMAMOTO Y, RUNOLD $M$, PRABHAKAR $N$, PANTALEO T (1988) Somatostatin in the control of respiration. Acta Physiol Scand 134: 529-533

ZAPATA P, LARRAÍN C (2005) How the carotid body works: Different strategies and preparations to solve different problems. Biol Res 38: 315-328

ZEYDA T, DIEHL N, PAYLOR R, BRENNAN MB, HOCHGESCHWENDER U (2001) Impairment in motor learning of somatostatin null mutant mice. Brain Res 906: 107-117 